\title{
Perbandingan prevalensi pterygium pada nelayan di Tuminting dengan petani di Rurukan
}

\author{
${ }^{1}$ Yusuf S. Tangdilintin \\ ${ }^{2}$ Laya M. Rares \\ ${ }^{2}$ Yamin Tongku
}

\author{
${ }^{1}$ Kandidat Skripsi Fakultas Kedokteran Universitas Sam Ratulangi Manado \\ ${ }^{2}$ Bagian Ilmu Kesehatan Mata Fakultas Kedokteran Universitas Sam Ratulangi Manado \\ Email: yusufsamjatangdilintin@gmail.com
}

\begin{abstract}
Based on Riset Kesehatan Dasar 2013, North Sulawesi is one of 10 provinces in Indonesia that have the highest pterygium prevalence. Previous findings at different areas showed that pterygium is more common at areas with high altitude than at areas with low altitude. Topography of North Sulawesi with mountains and hills might be related to the high prevalence of pterygium at this province. This study was aimed to obtain the difference in pterygium prevalence at area with high altitude compared to area with low altitude at North Sulawesi. This study used a cross sectional quantitative design and was conducted at Tuminting (mean altitude about $0 \mathrm{~km}$ above sea level) and at Rurukan (mean altitude about $1 \mathrm{~km}$ above sea level). There were 51 respondents at each location. Eye examination was performed and data about sun exposure were collected among fishermen at Tuminting and farmers at Rurukan. The results showed that the pterygium prevalence at Rurukan was $56.9 \%$ and at Tuminting was $41.2 \%$. Conclusion: There was a difference in pterygium prevalence between people at high altitude area from people at low altitude area at North Sulawesi.
\end{abstract}

Keywords: pterygium, altitude

\begin{abstract}
Abstrak: Berdasarkan hasil Riset Kesehatan Dasar 2013 Provinsi Sulawesi Utara termasuk dalam 10 provinsi dengan prevalensi pterygium tertinggi di Indonesia. Temuan sebelumnya di daerah yang lain menemukan prevalensi pterygium lebih tinggi di daerah dengan ketinggian dari permukaan laut yang tinggi dibandingkan daerah dengan ketinggian dari permukaan laut yang rendah. Topografi provinsi Sulawesi Utara yang sebagian besar terdiri dari pegunungan dan bukit-bukit mungkin berhubungan dengan tingginya prevalensi pterygium di Sulawesi Utara. Penelitian ini bertujuan untuk mendapatkan perbedaan prevalensi pterygium pada daerah dengan ketinggian yang tinggi dengan daerah dengan ketinggian yang rendah di Sulawesi Utara. Desain penelitian ialah potong lintang kuantitatif yang dilakukan di Tuminting (ketinggian rata-rata sekitar $0 \mathrm{~km}$ di atas permukaan laut) dan di Rurukan (ketinggian rata-rata sekitar $1 \mathrm{~km}$ di atas permukaan laut). Terdapat 51 responden pada tiaptiap lokasi penelitian dan dilakukan pemeriksaan mata serta pengumpulan data mengenai paparan terhadap matahari dari responden nelayan di Tuminting dan responden petani di Rurukan. Hasil penelitian mendapatkan prevalensi pterygium di Rurukan 56,9\% dan di Tuminting $41,2 \%$. Simpulan: Terdapat perbedaan prevalensi pterygium di daerah dengan ketinggian dari permukaan laut yang tinggi (Rurukan) dibandingkan daerah dengan ketinggian dari permukaan laut yang rendah (Tuminting) di Sulawesi Utara.
\end{abstract}

Kata kunci: pterygium, ketinggian daerah

Pterygium adalah pertumbuhan triangular dari jaringan fibroelastik tervaskularisasi yang timbul dari konjungtiva limbus dan meluas ke kornea. Jaringan ini mengganti- 
kan membran Bowman dan epitel kornea. ${ }^{1}$ Pterygium dapat terinflamasi sehingga menyebabkan rasa terbakar, iritasi, dan terasa seperti ada benda asing dalam mata. ${ }^{6}$ Gangguan ketajaman penglihatan dapat terjadi oleh karena astigmatisme yang diinduksi oleh pterygium atau karena halangan langsung bidang pandang mata oleh pterygium. ${ }^{2}$

Cameron $^{3}$ menuliskan bahwa pada daerah yang disebut sebagai "pterygium "belt $\left(37^{0}\right.$ Lintang Utara (LU) sampai $37^{0}$ Lintang Selatan (LS)) terdapat peningkatan prevalensi pterygium. $^{3}$

Terdapat penelitian di Nepal yang menemukan bahwa pertambahan prevalensi pterygium berbanding lurus dengan pertambahan ketinggian suatu daerah. ${ }^{4}$ Temuan ini sejalan dengan beberapa penelitian sebelumnya yang mendapatkan prevalensi pterygium yang tinggi di daerah dengan ketinggian yang tinggi dan prevalensi pterygium yang rendah di daerah dengan ketinggian yang rendah. ${ }^{5-8}$

Menurut hasil Riset Kesehatan Dasar (RISKESDAS) tahun 2013, prevalensi pterygium di Indonesia sebesar 8,3\%. Pekerjaan sebagai petani/nelayan/buruh mempunyai prevalensi pterygium tertinggi $(15.8 \%))^{9}$ Dari 33 Provinsi di Indonesia, Provinsi Sulawesi Utara menempati posisi ke-8 terbanyak pterygium. ${ }^{9}$

Kasus pterygium yang relatif banyak di Sulawesi Utara mungkin disebabkan karena kondisi topografi Provinsi Sulawesi Utara yang sebagian besar terdiri dari pegunungan dan bukit-bukit sesuai dengan pernyataan bahwa prevalensi pterygium meningkat berbanding lurus dengan peningkatan ketinggian suatu daerah.

\section{METODE PENELITIAN}

Penelitian ini menggunakan desain potong lintang kuantitatif. Responden ialah nelayan di Tuminting dan petani di Rurukan; tiap-tiap lokasi sebanyak 51 responden.

\section{HASIL PENELITIAN}

Di Rurukan, responden paling banyak berada pada usia $\geq 51$ tahun dan paling sedikit pada usia $\leq 20$ tahun sedangkan di Tuminting, responden paling banyak berada pada usia 21-30 tahun dan paling sedikit pada usia $\leq 20$ tahun (Gambar 1).

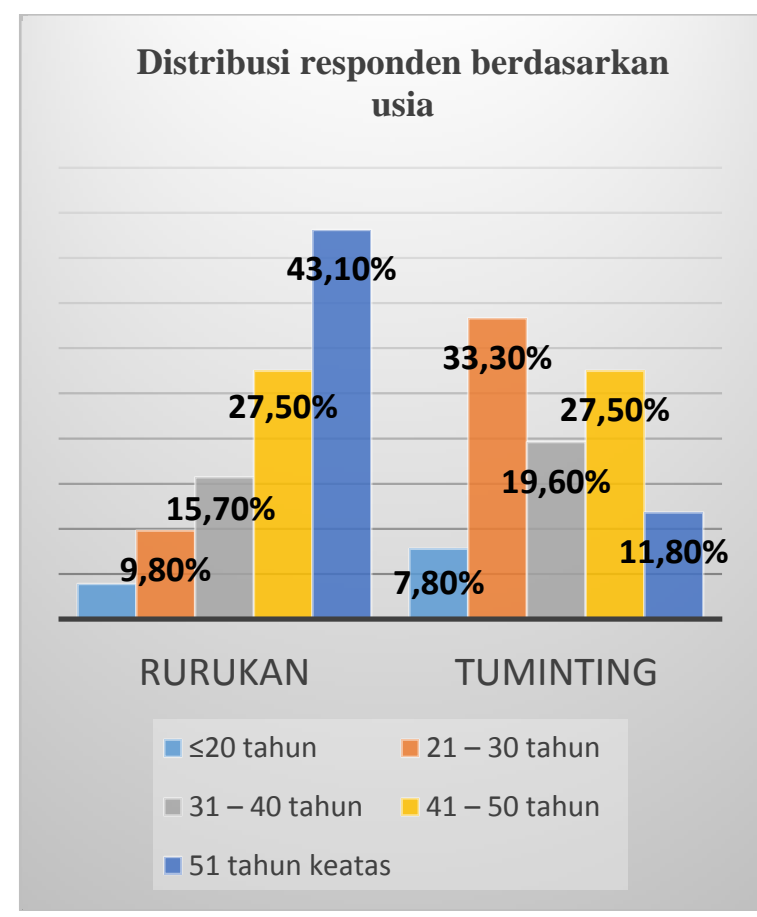

Gambar 1. Distribusi responden berdasarkan usia pada Rurukan dan Tuminting

Gambar 2 memperlihatkan di kedua lokasi penelitian responden dengan lama paparan rata-rata per hari terhadap matahari 10 tahun terakhirnya $>5$ jam lebih banyak daripada responden dengan lama paparan rata-rata per hari terhadap matahari 10 tahun terakhirnya $<5$ jam.

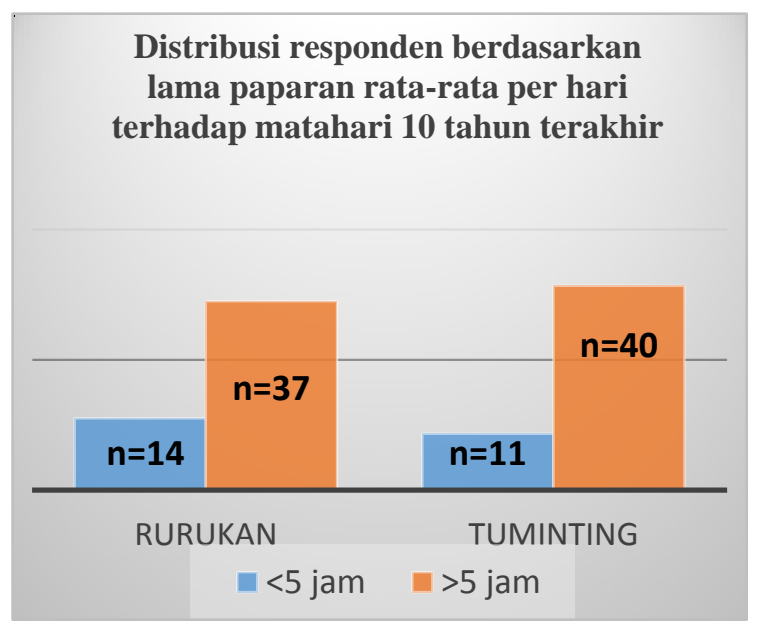

Gambar 2. Distribusi responden di Rurukan dan di Tuminting berdasarkan lama paparan rata-rata per hari terhadap matahari 10 tahun 
Di Rurukan lebih banyak responden yang telah bekerja sebagai petani selama $\geq 10$ tahun sedangkan di Tuminting lebih banyak nelayan yang baru bekerja sebagai nelayan selama $\leq 10$ tahun (Gambar 3).

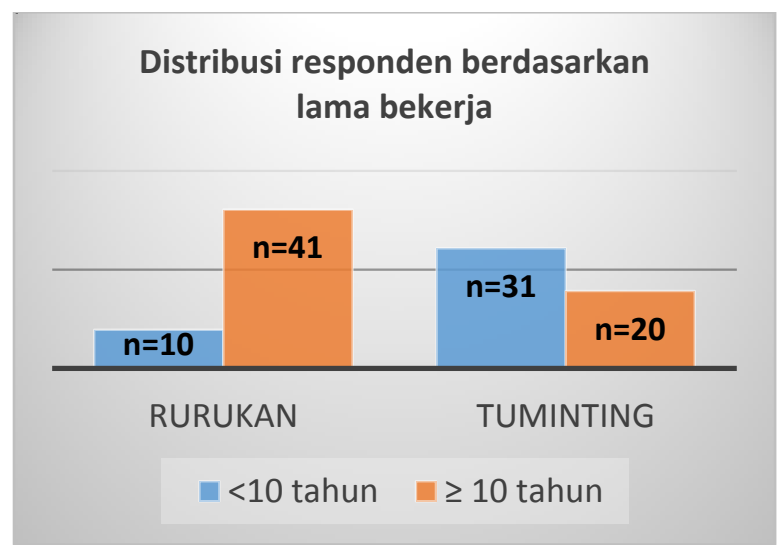

Gambar 3. Distribusi responden di Rurukan dan di Tuminting berdasarkan lama bekerja sebagai petani/nelayan

Prevalensi pterygium lebih besar pada petani di Rurukan dibanding nelayan di Tuminting (Gambar 4).

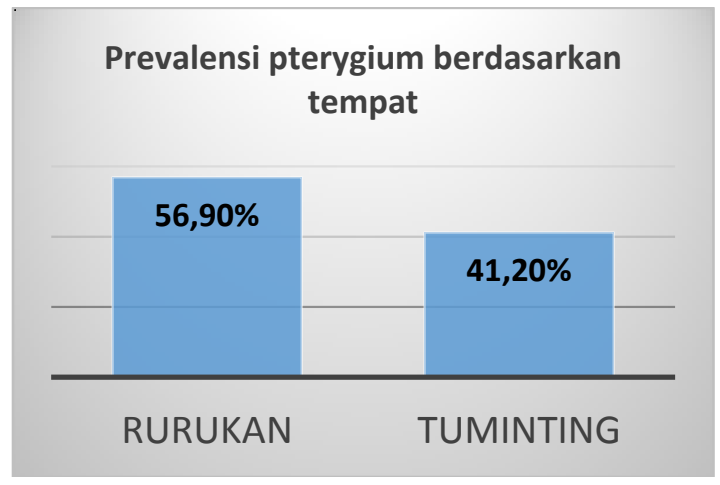

Gambar 4. Perbandingan prevalensi pterygium di Rurukan dengan di Tuminting

Di Tuminting prevalensi pterygium terbesar didapatkan pada kelompok responden dengan rentang usia $\geq 51$ tahun sedangkan di Tuminting prevalensi pterygium terbesar didapatkan pada kelompok dengan rentang usia 41-50 tahun (Gambar 5).

Di Rurukan prevalensi pterygium pada responden dengan lama paparan rata-rata per hari terhadap matahari 10 tahun terakhir >5 jam lebih besar daripada responden dengan lama paparan rata-rata per hari terhadap matahari <5jam sedangkan di Tuminting prevalensi pterygium pada responden dengan lama paparan rata-rata per hari terhadap matahari 10 tahun terakhir $>5$ jam lebih kecil daripada responden dengan lama paparan rata-rata per hari terhadap matahari 10 tahun terakhir $<5$ jam (Gambar 6).

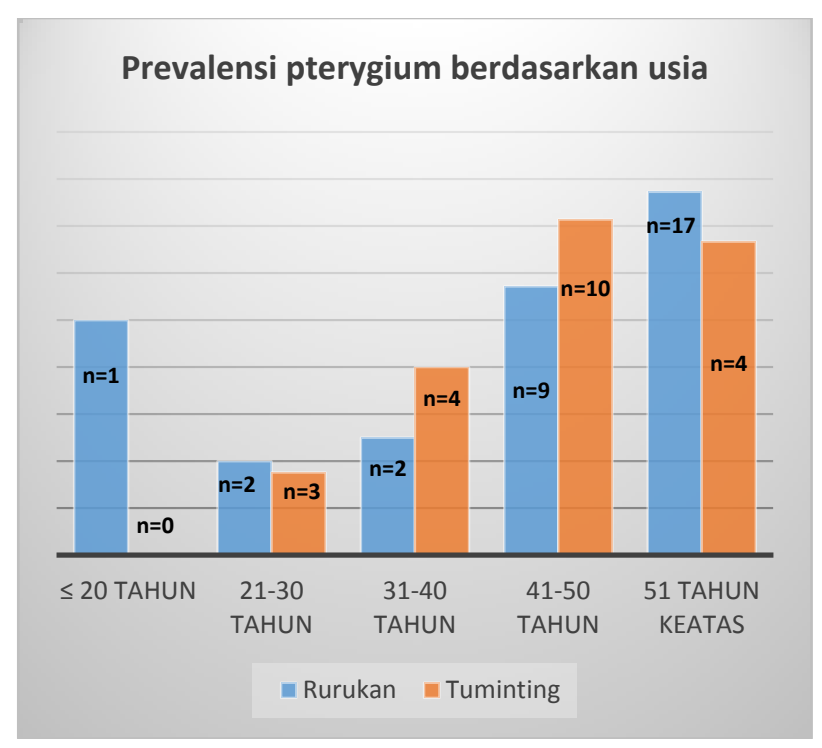

Gambar 5. Perbandingan prevalensi pterygium berdasarkan umur di Rurukan dan di Tuminting

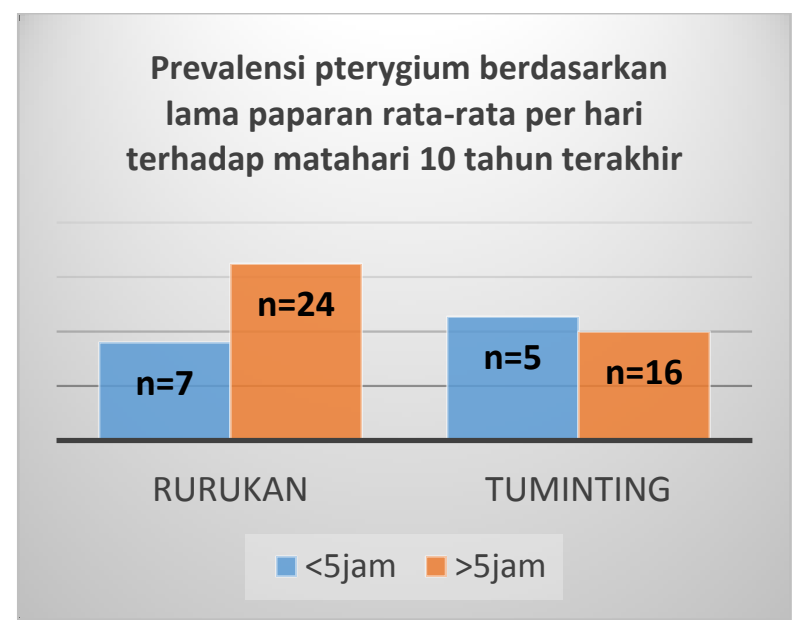

Gambar 6. Perbandingan prevalensi pterygium berdasarkan lama paparan rata-rata per hari terhadap matahari 10 tahun terakhir di Rurukan dan di Tuminting

Prevalensi pterygium pada responden dengan lama bekerja $\geq 10$ tahun lebih besar di Rurukan daripada responden di Tuminting (Gambar 7). 


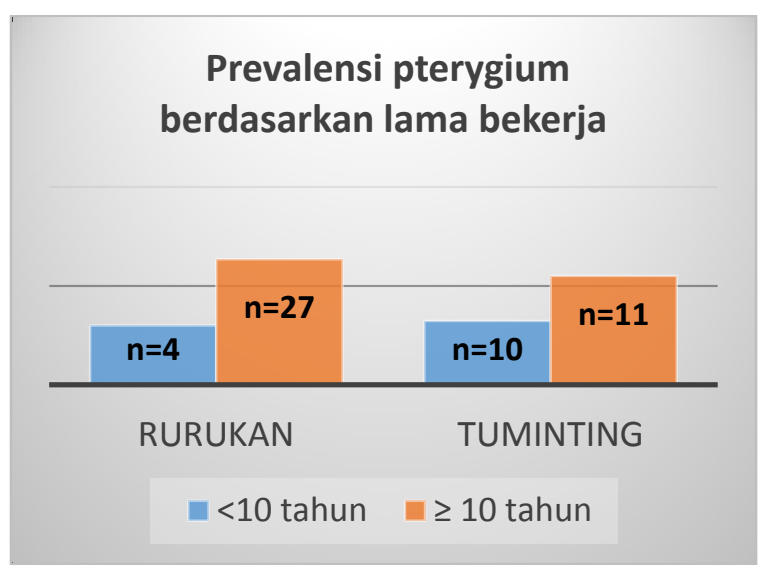

Gambar 7. Perbandingan prevalensi pterygium berdasarkan lama bekerja sebagai petani di Rurukan dan sebagai nelayan di Tuminting

Prevalensi pterygium lebih tinggi pada responden dengan lama paparan rata-rata per hari terhadap matahari 10 tahun terakhir $>5$ jam dan lama bekerja $\geq 10$ tahun di Rurukan daripada responden di Tuminting (Gambar 8).

Prevalensi pterygium pada subjek dengan lama paparan rata-rata per hari terhadap matahari 10 tahun terakhir $>5$ jam dan lama bekerja $\geq 10$ tahun

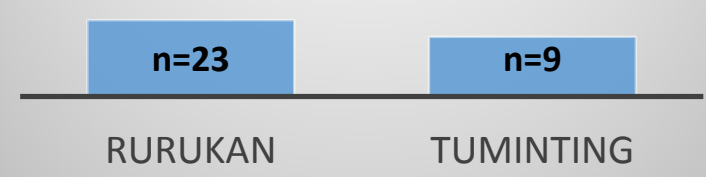

Gambar 8. Perbandingan prevalensi pterygium pada subjek dengan lama paparan rata- rata per hari terhadap matahari 10 tahun terakhir $>5$ jam dan lama bekerja $\geq 10$ tahun

\section{BAHASAN}

Dari hasil penelitian yang dilakukan didapatkan prevalensi pterygium lebih besar pada petani di Rurukan (daerah yang lebih tinggi) dibandingkan dengan nelayan di Tuminting (daerah yang lebih rendah). Pada penelitian sebelumnya juga terdapat prevalensi pterygium yang tinggi pada daerah dengan ketinggian dari permukaan laut yang tinggi antara lain $17,9 \%$ pada populasi Mongol yang tinggal di Henan (ketinggian rata-rata $3450 \mathrm{~m}$ ), 14,49\% pada Zeku China (ketinggian rata-rata $3700 \mathrm{~m}$ ) dan prevalensi pterygium yang rendah pada daerah dengan ketinggian dari permukaan laut yang lebih rendah yaitu 3\% (ketinggian $850 \mathrm{~m} \mathrm{~s})^{8,10,11}$

Pada kedua populasi yang dibandingkan didapatkan prevalensi pterygium yang lebih tinggi di Rurukan (daerah yang lebih tinggi). Hal ini mungkin berkaitan dengan efek kumulatif paparan UV dan usia.

Temuan pada Gambar 8 yaitu prevalensi pterygium yang tinggi pada responden dengan lama paparan-rata-rata per hari terhadap matahari $>5$ jam dan lama bekerja sebagai petani/nelayan $\geq 10$ tahun di kedua lokasi $(71,875 \%$ pada petani dan $56,25 \%$ pada nelayan) mengisyaratkan efek kumulatif UV mungkin berpengaruh terhadap terbentuknya pterygium . Terdapat penelitian sebelumnya yang menyebutkan bahwa subjek dengan lama paparan kumulatif seumur hidup terhadap matahari yang lebih besar lebih banyak terkena pterygium daripada subjek dengan lama paparan kumulatif seumur hidup terhadap matahari yang lebih kurang. ${ }^{12}$ Chui et al. ${ }^{13}$ berasumsi bahwa kerusakan genetik kumulatif akibat paparan UV kronis sebagai etiologi pterygium. ${ }^{13}$

Pada Gambar 6, 7, dan 8 didapatkan prevalensi pterygium yang lebih tinggi pada responden dengan paparan matahari yang besar di Rurukan dibandingkan dengan responden di Tuminting. Bila mengabaikan karakteristik usia responden yaitu yang berusia $\geq 41$ tahun lebih banyak di Rurukan daripada di Tuminting hal ini mungkin mengisyaratkan lebih besarnya dampak akibat gelombang UV pada mata di daerah yang lebih tinggi dibandingkan dengan daerah yang rendah oleh karena intensitas radiasi UV lebih besar di daerah yang lebih tinggi (menurut WHO: peningkatan intensitas radiasi UV 10\% setiap pertambahan ketinggian $1 \mathrm{~km}) .{ }^{14}$ Dengan demikian risiko terbentuknya pterygium mungkin lebih besar di daerah yang lebih tinggi. Karakteristik responden tetap harus diperhatikan karena pada studi sebelumnya didapatkan prevalensi pterygium yang tinggi pada subjek berusia $\geq 40$ tahun yaitu $13 \%$ di Central Sahara Afrika, dan 30,8\% 
di pulau Kumejima. ${ }^{15,16}$ Pada Gambar 5 juga dapat dilihat prevalensi pterygium yang besar pada responden berusia $\geq 41$ tahun di kedua lokasi penelitian. Pada studi ini, prevalensi pterygium yang lebih tinggi di daerah yang lebih tinggi mungkin bukan disebabkan oleh lebih besarnya efek gelombang UV terhadap mata tetapi karena lebih banyak responden yang berusia $\geq 41$ tahun di daerah itu.

Selain paparan terhadap ultraviolet dan faktor usia terdapat juga faktor-faktor lain seperti angin, pasir/debu, dan faktor herediter yang berkaitan dengan munculnya pterygium. $^{15,17}$ Faktor-faktor tersebut tidak diteliti dalam penelitian ini.

Keterbatasan penelitian ini ialah penentuan responden dengan pterygium hanya berdasarkan inspeksi langsung mata; paparan terhadap matahari hanya ditentukan dari hasil wawancara; terdapat responden yang pekerjaannya sebagai petani hanya sebagai pekerjaan sampingan; perbedaan proporsi jumlah responden dengan usia $\geq 41$ tahun yaitu lebih banyak pada petani di Rurukan; dan jumlah responden penelitian masih kurang. Penelitian lebih lanjut perlu dilakukan.

\section{SIMPULAN}

Terdapat perbedaan prevalensi pterygium antara masyarakat yang tinggal di daerah dengan ketinggian daerah yang rendah dibandingkan dengan masyarakat yang tinggal di daerah dengan ketinggian daerah yang tinggi di Sulawesi Utara.

\section{DAFTAR PUSTAKA}

1. Das S, Kurian M, Shetty R, Nagappa S, Nanaiah SG. In: Chakrabarti A, penyunting. Cataract surgery in diseased eyes (1st ed). New Delhi: Jaypee Brothers Medical Publisher (P) Ltd, 2014.

2. Farhood QK, Kareem AA. Pterygium and induced astigmatism. Kufa Med J. 2012;15(1).

3. Cameron ME: Pterygium throughout the world. Springfield, Ill: Charles C. Thomas, 1965.

4. Shrestha S, Shrestha SM. Comparative study of prevalence of pterygium at high altitude and Kathmandu Valley. J Nepal Health Res Counc. 2014; 12(28):187-90.

5. Lu P, Chen X, Kang Y, Ke L, Wei X, Zhang W. Pterygium in Tibetans: a population-based study in China. Clin Exp Ophthalmol. 2007;35:823-33.

6. Maharjan IM, Shrestha E, Gurung B, Karmacarya S. Prevalence of and associated risk factors for pterygium in the high altitude communities of Upper Mustang, Nepal. Nepal J Ophthalmol. 2014;6(2):65-70.

7. Zhong H, Cha X,Wei T, Lin X, Li X, Li J, et al. Prevalence and risk factor for pterygium in rural adult Chinese populations of the Bai nationality in Dali: The Yunnan Minority Eye Study. Invest Ohthalmol Visual Sci. 2012;53:6617-21.

8. Sarac O, Toklu Y, Şahin M. The prevalence of pterygium in Ankara: a hospitalbased study. Turkish J Med Sci. 2012;42:1006.

9. Riset kesehatan dasar 2013. Badan penelitian dan pengembangan kesehatan Kementrian RI. 2013.

10. Lu J, Wang Z, Lu P, Chen X, Zhang W, Shi $K$, et al. Pterygium in an aged Mongolian population: A population-based study in China. Eye. 2009;23:421-7.

11. Lu P, Chen $X$, Kang $Y$, Ke L, Wei X, Zhang W. Pterygium in Tibetans: A population-based study in China. Clin Exp Ophthalmol. 2007;35: 828-33.

12. Mackenzie FB, Hirst LW, Battistutta D. Risk analysis in the development of pterygia. Ophthalmol. 1992;99(7): 1056.

13. Chui J, Coroneo MT, Tat LT, Crouch R, Wakefield D, Girolamo ND. Ophthalmic pterygium: a stem cell disorder with premalignant features. American society for investigative pathology. 2011;178(2):817-27.

14. Ultraviolet radiation and the Intersun Programme. WHO. [cited 13 Oktober 2015]. Available from: http://who.int/uv/uv_and_health/en/

15. Bueno-Gimeno I, Montes-Mico R, EspanaGregori E, Pons AM. Epidemiologic study of pterygium in a Saharan population. Ann Ophthalmol. 2002;34:43-6. 
Tangdilitin, Rares, Tongku: Perbandingan prevalensi pterygium...

16. Shiroma H, Higa A, Sawaguchi S, Iwase A, Tomidokoro A, Amano S, et al. Prevalence and risk factors of pterygium in a southwestern island of Japan: the Kumejima Study. Am J
Ophthalmol. 2009;148(5):766-771.

17. Anguria P, Kitinya J, Ntuli S, Carmichael

T. The role of heredity in pterygium development. Int $\mathbf{J}$ Ophthalmol. 2014;7(3):563-73. 